\title{
AFFECTING THE DESIGN PARAMETERS OF RIDGER FURROW OPENER AND PLANTING METHODS ON SUGAR BEET YIELD AND WATER USE EFFICENCY
}

\author{
MAREY, S. A. \\ Agricultural Engineering Research Institute (AENRI), ARC, Doki, Giza, Egypt \\ (Manuscript received 2 April 2014)
}

\begin{abstract}
Design parameters of the ridger furrow opener directly affecting the furrow profile characteristics and the amount of applied water. Furrow-bed irrigation technique is usually used for water conservation, efficient fertilizer use and many other benefits. This study was to evaluate the impact of design parameters of the ridger furrow opener and planting methods on sugar beet yield and water use efficiency. Therefore, field experiments were conducted to (i) investigate the effects of share rake angles $\left(20^{\circ}, 25^{\circ}\right.$ and $30^{\circ}$ ), opener wing angles $\left(35^{\circ}\right.$ and $45^{\circ}$ ) and wing shapes (straight and curved) on the furrow profile characteristics, transverse scattering, draft force, and (ii) evaluate planting methods (i.e. ridges with $50 \mathrm{~cm}$ rows spacing and pair of rows on bed with 30, 35 and $40 \mathrm{~cm}$ rows spacing), the wing shape and angles on the percentage of emergence, sugar percentage, root and sugar yield, applied water and water use efficiency. The results showed that the curved shape and the wing angle of $45^{\circ}$ produced wider furrows than those produced by the straight shape and $35^{\circ}$ wing angle. Minimum transverse scattering was associated with the curved wing, wing angle of $35^{\circ}$ and share rake angle of $20^{\circ}$. Increasing the share rake and wing angles increased the required draft force. The highest average values of root and sugar yields could be achieved by planting beet in beds with $30 \mathrm{~cm}$ rows spacing flowed by beds with 35 and $40 \mathrm{~cm}$ rows spacing, respectively. The lowest value of the water use efficiency was achieved by planting on ridges compared to the other planting methods. The maximum emergence percentage, root and sugar yields, sugar percentage and water use efficiency were associated with a wing angle of $45^{\circ}$ and the curved wing shape.
\end{abstract}

Keywords: Sugar beet, power requirements, yield, furrow profile, applied water, bed planting.

\section{INTRODUCTION}

Optimum population of plants on well-spaced rows has been found to produce good yield and quality in most of the arable crops. Good plant stand gives a complete occupation of the available space, and plant can receive light from all sides, i.e., complete light interception, (Zahoor et. al., 2010). Scott and Jaggard (1978) found a close relationship between solar radiation intercepted by a sugar beet crop and the yield. Egypt is considered as a country of water scarcity due to the low precipitation, high evaporation and temporal and spatial distribution of rainfall, and the land 
resources are limited (Abo-Shady et. al., 2010). In such regions, bed planting is one of the most renowned techniques used for saving water, efficient fertilizer use and many other benefits. Bed planting technique has been tested for several crops, it significantly improved the relationship of soil-water, nutrient, and the root growth of plants (Ren et. al., 2013). Chaudhry et. al., (1994) reported that furrow bed system saved about $25-53 \%$ of water and increased the yield of cotton crop by $6-52 \%$ as compared to basin system. In addition to the water saving, bed planting also improves the efficiency of fertilizer, reduces weed infestation and reduces seed rate without sacrificing yield. Irrigation water consumption in ridge and furrow planting depends mainly on the wide of furrow and the furrow profile as well, (Hu et. al., 1997). The design parameters of the furrow opener such as the share rake angle and wing shape and angle strongly affect the shape of the ridge profile. In addition, one of the most important parameters strongly affect the required draft force is the share rake angle. For better penetration of soil, the rake angle of the share should be $\geq 25^{\circ}$ to the ground (Abd El-Tawwab et al. 2007). However, Zhang and Araya (2001) reported that the draft force of a mold board plough had increased steeply when rake angle was more than $30^{\circ}$. The rake angle of the furrow opener that gave a minimum specific draft for a lateritic sandy clay loam soil was 28 (Mathur and Pandey 1992), while, Vashney and Patel (1988) reported that the minimum draft required for a cultivator shovel at different levels of soil moisture in a light soil was associated with $30^{\circ}$ share rake angle. Acvarshney et. al. (2006) investigated the effect of share rake angle of mould board plough and sweep on the draft force requirement in a clay soil .They reported that the minimum specific draft was found with rake angles ranged from $25^{\circ}$ to $29^{\circ}$ with the sweep at soil moisture content of $21 \%$. The sweep angle also affects the draft requirement and the furrow profile, increasing share sweep angle increased the draft force (Fielke, 1988). In Egypt, sugar beets are grown on raised planting beds to facilitate furrow irrigation. The common arrangement of rows is a single row centered on beds $60 \mathrm{~cm}$ apart.

Therefore, the objectives of the current study were to: (i) Study the effect of some design parameters of furrow openers (e.g., share rake angle, wing angle and wing shape) on the furrow profile, seeds transverse scattering, and draft force requirements. (ii) Study the effect of planting methods (i.e., ridges and bed planting with different row-row spaces) on emergency, sugar parentage, root and sugar yield and water use efficiency. 


\section{MATERIALS AND METHODS}

\section{Experimental design}

Two field experiments were conducted in a private farm at Kafer Elsheikh governorate, Egypt, $\left(31^{\circ} 8 \mathrm{~N}, 30^{\circ} 41^{\circ} \mathrm{E}\right)$ in 1.75 hectare during agricultural season of 2011/2012. The field soil was mainly clay loam with a bulk density in the range between 1.31 and $1.44 \mathrm{~g} . \mathrm{cm}^{-3}$. Soil was prepared using chisel plough (7 shanks) two passes, disc harrow, and LASER leveling with $0.5 \%$ slop. The first experiment was to evaluate the impact of some design parameters of furrow openers in a ridging unit on furrow profile, transverse scattering, and power requirements. These parameters are the share rake angles $\left(20^{\circ}, 25^{\circ}\right.$, and $\left.30^{\circ}\right)$, wing angle $\left(35^{\circ}\right.$ and $\left.45^{\circ}\right)$, and wing shape (straight and curved, Fig.1). Experimental treatments were laid out in split-split plot design with three rake angles as the main treatments, two opener's wing angles as the sub treatment and two wing shapes as the sub-sub treatment. These experiments were conducted in ridges $50 \mathrm{~cm}$ apart with the planter forward speed of $3.5 \mathrm{~km} . \mathrm{hr}^{-1}$ and $15 \mathrm{~cm}$ ridging depth.

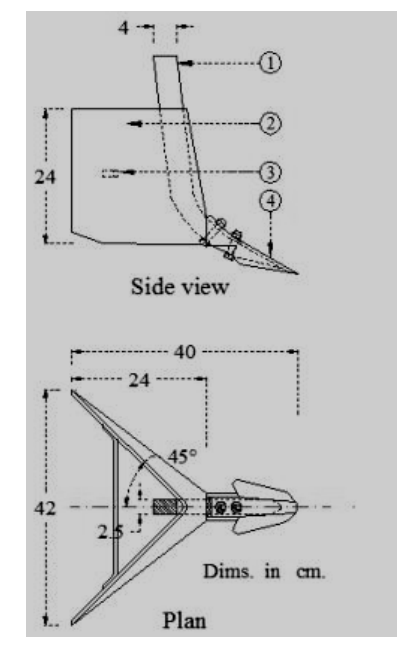

(a) straight

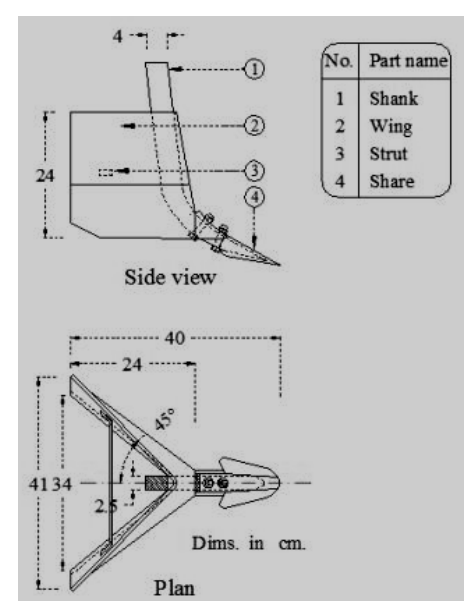

(b) curved

Fig . 1. Shape of the opener wings

The second experiments were to evaluate four planting methods (ridges with $50 \mathrm{~cm}$ row space and beds having pair of rows on bed of 30,35 and $40 \mathrm{~cm}$ distance between rows), two wing shapes (straight and curved), and two wing angles ( $35^{\circ}$ and $45^{\circ}$ ). This is to investigate the effect of these parameters on emergence, sugar percentage, root and sugar yields, water applied and water use efficiency. The 
experimental plots were arranged in spilt- split plot design. The main plot was for the planting methods, the sub plot was for the wing angles and sub-sub plot was for the wing shape. In all experiments, different combinations of treatments were repeated three times (replicates). In the available conventional planters (e.g., Gaspardo Seminatrici SPA, Fig. 2(a)), the minimum distance between each two furrow openers is $60 \mathrm{~cm}$. It is well known that reducing the distances between rows would increase the number of plants per unit area. Accordingly, Gaspardo Seminatrici SPA planter was modified at the workshop of Delta sugar Co., (Kafer Elsheikh Factory). Several pre trails have been made to adjust a relatively low distance between the ridges of the planter. The minimum distance could be obtained was $50 \mathrm{~cm}$ without affecting the ridges centerlines (location of dropping the seeds).

This modification was accomplished by fixing a steel beam (i.e., toolbar, $15 \mathrm{x}$ $15 \mathrm{~cm}$ cross sectional area, and $0.7 \mathrm{~cm}$ thickness) in the front of the planter (Fig. 2 b). The ridger furrow openers were attached with this beam instead of the main planter frame in the conventional design. Three square tubes, each with cross sectional area of $8 \times 8 \mathrm{~cm}$ and $0.6 \mathrm{~cm}$ thick, were welded and used to fix the hitch points with the beam (Fig. 2b). The modified toolbar can be simply fixed to the planter and makes it available to be used for other crops by separating this unit when needed. In addition, curved wing shape was designed fabricated (Fig. 1 b) to compare with the conventional wing shape (i.e., straight). Seeds of sugar beet cultivar (Multigerm Montbuanco) were sowed in $13^{\text {th }}$ September 2011 and the crop harvesting was done in $17^{\text {th }}$ April 2012. Fertilizers were added according to the technical recommendation of the Ministry of Agriculture at rates of $214 \mathrm{~kg} \mathrm{~N}, 36 \mathrm{~kg} \mathrm{P}_{2} \mathrm{O}_{5}$ and $238 \mathrm{~kg} \mathrm{~K}_{2} \mathrm{SO}_{4}$ per hectare. Nitrogen fertilizer was applied in two equal doses before the first and the second irrigations. Phosphorus was broadcast before planting as Super Phosphate $\left(15.5 \% \mathrm{P}_{2} \mathrm{O}_{5}\right)$. Potassium was applied by topdressing in one application of Potassium Sulphate $\left(48 \% \mathrm{~K}_{2} \mathrm{O}\right)$ before the first irrigation. Furrow irrigation of sugar beet was used and controlled by the siphon method FAO (1974) and irrigation water was applied every 21 days (Irrigation intervals). 


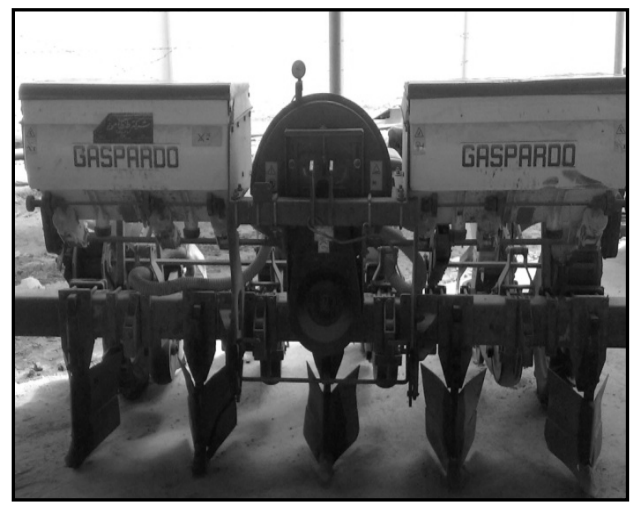

(a)

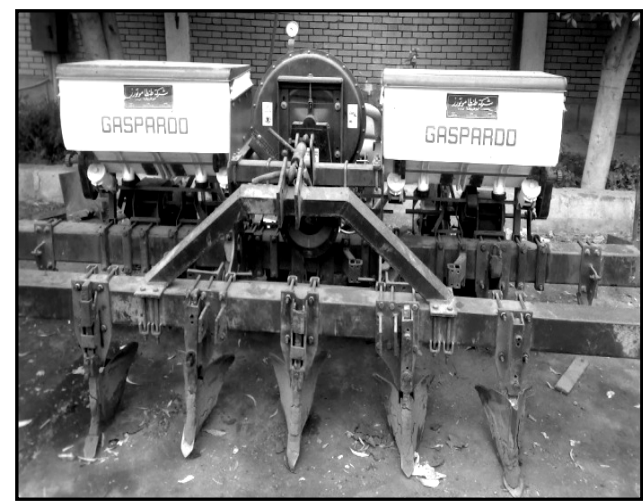

(b)

Fig . 2. Photo of the planter before modification (a) and after modification (b).

\section{Experimental measurements}

During executing these experiments the following indicators have been measured:

(i) Furrow profile characteristics were measured by using a pin meter that was designed according to Römkens et. al., (1986) and Wagner and Yi 'ming, (1991). This meter is a row of probes holed in a horizontal rectangular steel bar, spaced at $5 \mathrm{~cm}$ intervals, the props designed to slide up and down into the holes of the bar to make their tips just to touch the soil surface. Accordingly, the pines positions were recorded manually, and then characteristics of each furrow profile were determined.

(ii) The transverse scattering of seeds placement was determined statistically by estimating the standard deviation of the distances between each seed and the row centerline. Thus, the slandered deviation $(\mathrm{Std}, \mathrm{cm})$ is given by:

$$
\mathrm{Std}=\sqrt{\frac{\sum \mathrm{X}^{2}-(\Sigma \mathrm{X})^{2} / \mathrm{n}}{\mathrm{n}-1}}
$$

Where $\mathrm{X}$ is the distance between the seed and the row centerline in $\mathrm{cm}$ and $\mathrm{n}$ is the number of observations.

( iii) Rolling resistance and draft force to determine the draft force $(F, k N)$ that is required for the planting operation, two tractors were used, one is to hang-up and pull the planter and the other is to pull both (the planter with the tractor). A hydraulic dynamometer was fixed between the two tractors to measure the drawbar pull (DF, $\mathrm{kN}$ ) during operation. Ten readings were recorded for each treatment and the mean 
value was obtained. The rolling resistance $(R R, k N)$ of the tractor with the planter was determined at no load (lifted position) by the dynamometer methods at sowing speed. The net draft force $(F, k N)$ was estimated as:

$F=D F-R R$

(iv) The emergence percentage $\left(G_{p} \%\right)$ was estimated by accounting the number of plants ( $P$ ) and the number of delivered seeds (S) for each treatment. This was performed for the 2 central rows of each treatment and after 25 days from sowing. Accordingly, $G_{p}$ was calculated as:

$G_{p}=P / S \times 100$

(v) The amount of applied water (IW, $\mathrm{m}^{3} \mathrm{ha}^{-1}$ ) for each treatment was measured by using a siphon tubes. Siphon tubes, $2 \mathrm{~m}$ length and $50 \mathrm{~mm}$ diameter, were calibrated by using a container and a stopwatch to calculate the flow rate of the tubes. The inflow rate was constant during the irrigation periods of the treatments. Water use efficiency (WUE, $\mathrm{Mg} \mathrm{m}^{-3}$ ) was calculated according to Jensen, (1983) as:

WUE $=Y / I W$

where $\mathrm{Y}$ is the root yield, in $\mathrm{Mg} \mathrm{ha}^{-1}$, was estimated for the central three ridges of each plot .

(vi) The sugar yield $\left(\mathrm{Mg} \mathrm{ha}^{-1}\right)$ was estimated as the percentage of sucrose multiplied by root yield $(\mathrm{Y})$. The percentage of sucrose was estimated for the fresh harvested roots by using an Automatic Sugar Polarimeter as described by McGinnus, (1982) at Delta Sugar Co. Ltd. , (El-Hammol, Kafr El-Sheikh Governorate, Egypt).

\section{RESULTS AND DISCUSSION}

Two field experiments were conducted, the first was to investigate the effect of share rake angle, wing shape and wing angle on the furrow profile, transverse scattering and draft force requirements, the second was to evaluate the effect of planting methods, wing shape and angle on seedling emergency, sugar percentage, root and sugar yield, and water use efficiency.

\section{Effect of share rake angle, wing shape and wing angle on: Characteristics of furrow profile}

The furrow profile at different share rake angles and wing angles as well as wing shape was illustrated in Figs ( 3 and 4$)$. The general trend of furrow profiles shown in Figs. ( $3 \& 4)$ indicated that the furrow depth was proportional to the share 
rake angle. The highest furrow depth associated with the rake angle of $30^{\circ}$. This trend was due to the increase of the share penetration into the soil by increasing the share rake angle. These results agree with those reported by Varshney et. al., (2006) and Abd El-tawwab et al, (2007). For all rake and wing angles used in this study, the edge of the bed and the depth of furrow performed by the curved wing were higher than those performed by the straight wing. This may attributed to the collapse the soil inside furrows performed by the straight wings immediately after it formed. Increasing wing angle tends to increase the furrow width due to increase the soil cross-sectional area that moves in the front of the share having a wing angle of $45^{\circ}$ compared to wing angle of $35^{\circ}$ for all the share rake angles and wing shapes.

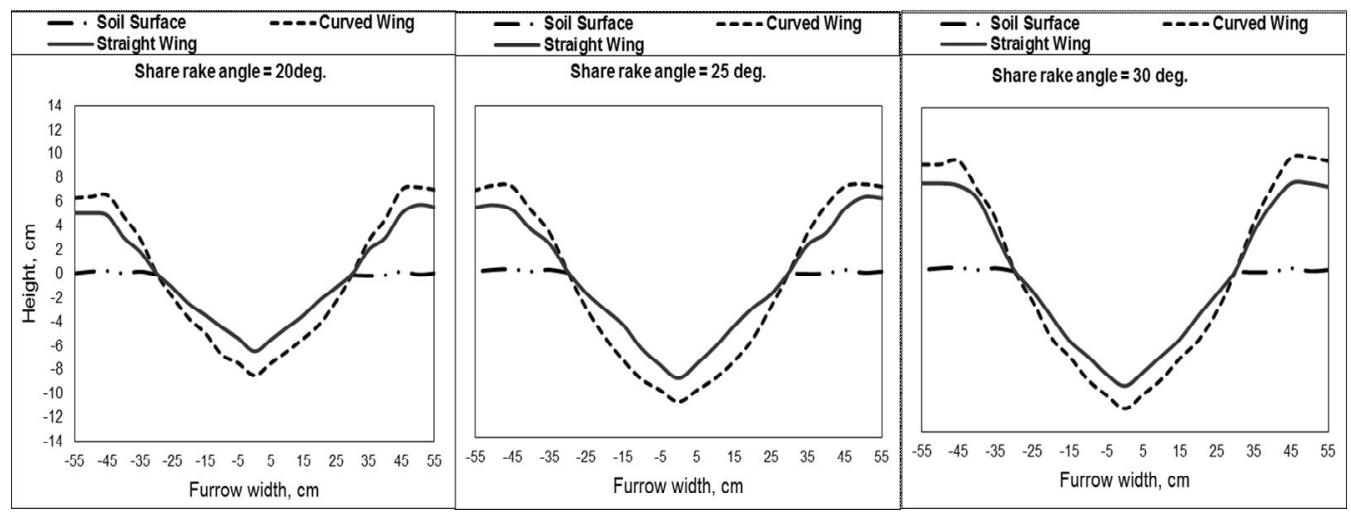

Fig. 3. Furrow profile as influenced by share rake angle and wing shape for a wing angle of $45^{\circ}$.

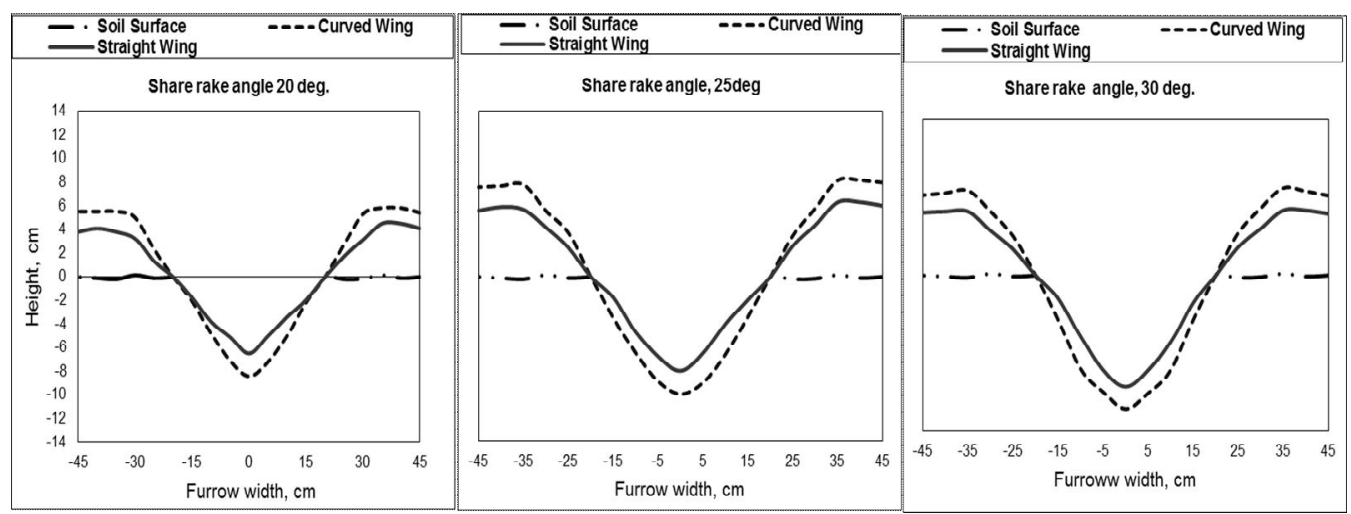

Fig . 4. Furrow profile as influenced by share rake angle and wing shape for a wing angle of $35^{\circ}$.

\section{Seeds transverse scattering}

Standard deviation tells the dispersion of seeds from the optimum location (i.e., the row centerline). The standard deviation at different share rake angles, wing angles and wing shapes are presented in Fig (5). At given wing angles and shape, the 
standard deviation was observed to increase with increasing share rake angle. For example, a decrease in the share rake angle from 30 to 20 caused a drop in the standard deviation from 2.9 to $2.04 \mathrm{~cm}$ at a wing angle of $35^{\circ}$ and straight wing shape. This attributed to increase the soil movement and machine vibration as affected by increasing the share rake angle, this makes the seed to move with the soil away from the ridge centerline. For all share rake angles and both wing shapes, the maximum standard deviation occurred when the wing angle was $45^{\circ}$, and the minimum standard deviation could be achieved when the wing angle was $35^{\circ}$. This may be attributed to the stability of seeds on the ridge in case of $35^{\circ}$ wing angle was higher than that of $45^{\circ}$ wing angle due to seed dropping down away from edge of the ridge. Also, the lower values of the standard deviation were recorded with the curved wing compared to the straight wing for all wing and rake angles.

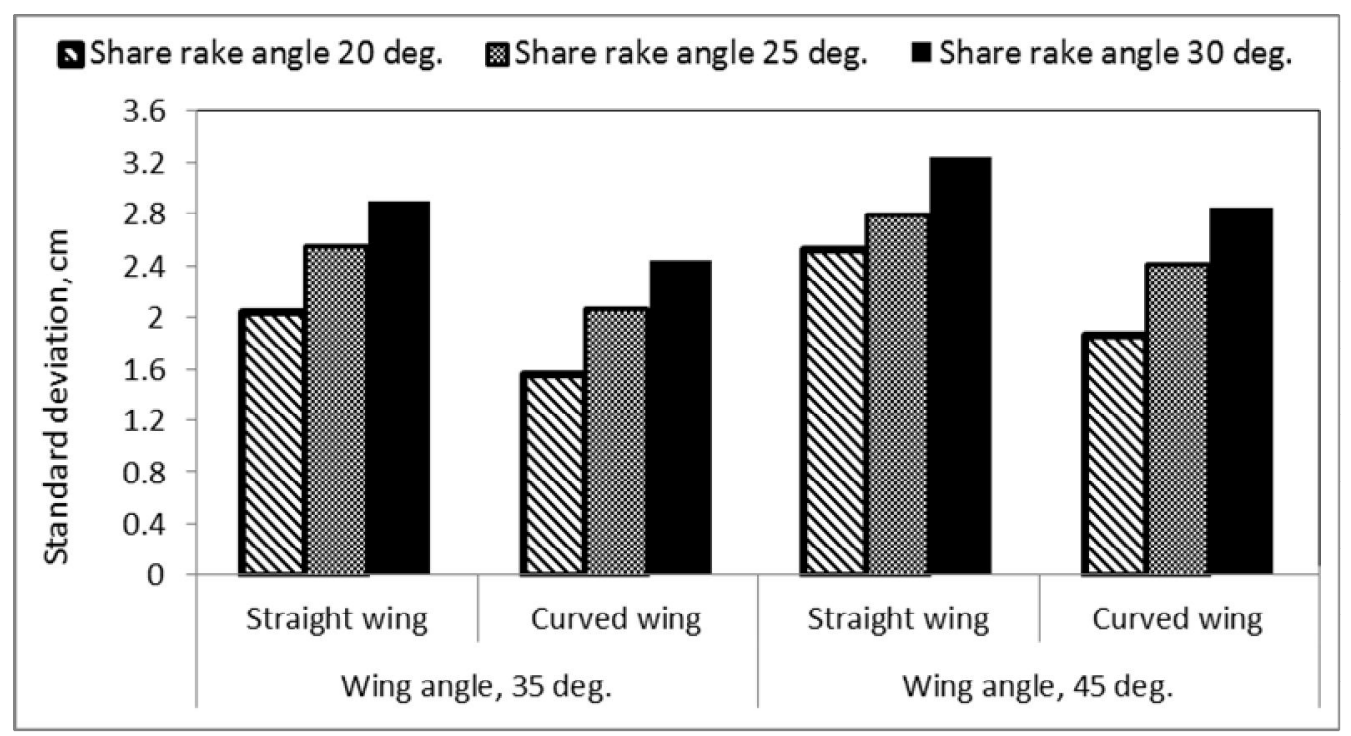

Fig .5. Effect of share rake angle, wing angle and wing shape on standard deviation of seeds scattering from the row centerline, $\mathrm{cm}$

\section{Draft requirements}

Data of the net draft force required for the planter as affected by the different parameters considered is shown in Fig. (6). The minimum net draft was found to be associated with the rake angle of $20^{\circ}$ at the different wing shapes and angles. Increasing the rake angle to $30^{\circ}$ was observed to increase the required net draft force. These results were in agreement with those obtained by Abd El-tawwab et al (2007). Increasing wing angle tends to increase the net draft force due to the increase of the cross sectional area of the moving soil in the front of furrow opener and the resistance force as well. It can be seen from Fig. 6 that the highest values of the net draft forcers were recorded with the curved wing compared to the straight 
wing at all rake and wing angles due to increasing the frictional surface area of the curved wing compared to the straight wing.

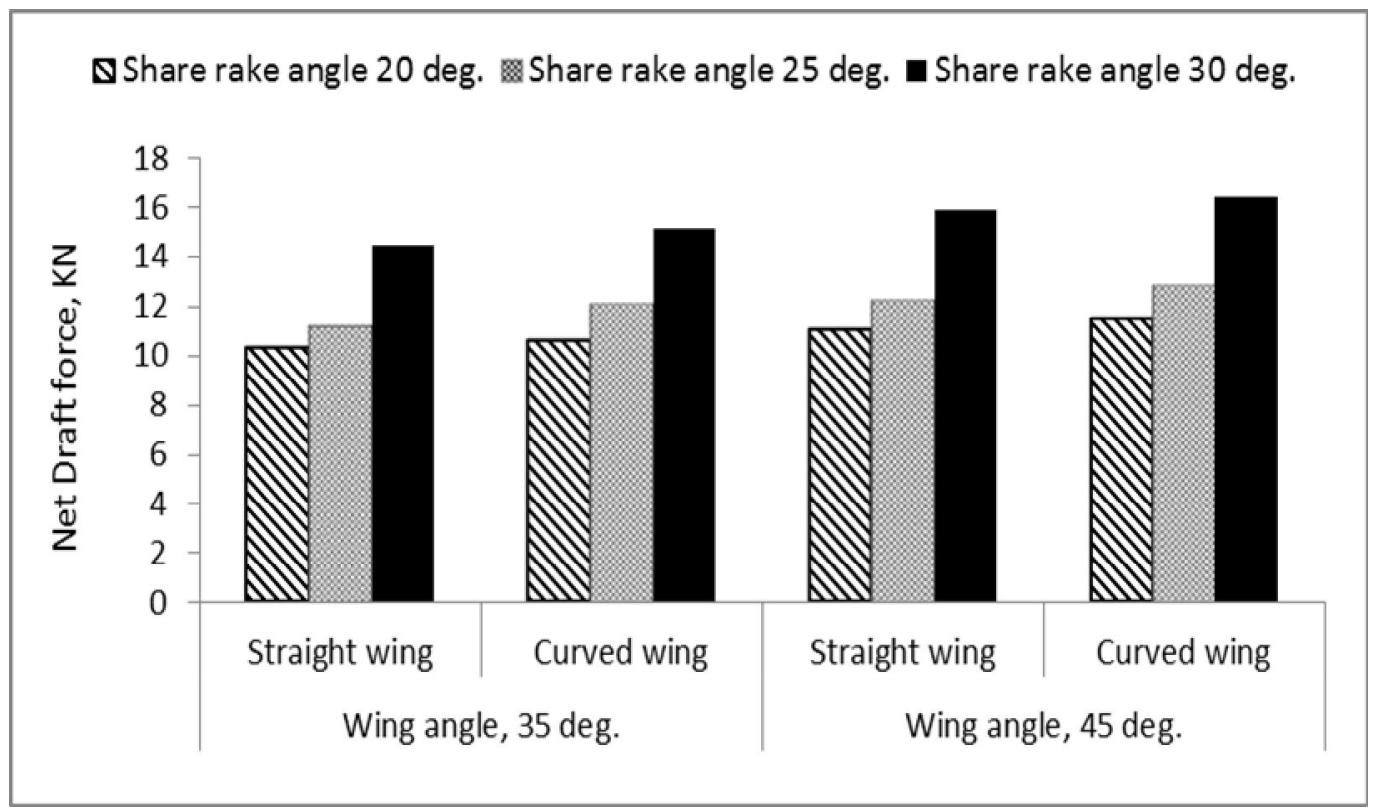

Fig . 6. Effect of share rake angle, wing angle and wing shape on net draft, kN.

\section{Effects of planting methods, wing shape and wing angle on:}

\section{Emergence percentage}

The statistical analysis indicated that the planting methods had no significant effect on the emergence percentage (Table 1). However, the germination percentage varied significantly $(P<0.01)$ under different wing angles and shapes (Table 1$)$. The average emergence percentages under different planting methods, wing shapes, and angles are presented in Table 2. Wing angle of $45^{\circ}$ gave a higher emergence (89.22 $\%)$ as compared to $35^{\circ}$ wing angle $(87.81 \%)$. A wider furrow increases the water flow, therefor water could not reach at ridge top which produced a warm bed area that enhances the germination percentage. The curved wing produced a higher germination percentage than the straight wing (Table 2). This may attributed to collapse of soil inside the furrow which impedes the water flow and increases its level inside the furrow. 
Table 1. Two way analysis of variance for different sugar beet parameters.

\begin{tabular}{|c|c|c|c|c|c|c|}
\hline SOV & $\begin{array}{c}\text { Seed } \\
\text { emergenc } \\
\text { e, \% }\end{array}$ & $\begin{array}{c}\text { Root. yield, } \\
\text { Mg.ha-1 }\end{array}$ & $\begin{array}{l}\text { Sugar } \\
\text { percentag } \\
\text { e., \% }\end{array}$ & $\begin{array}{l}\text { Sugar } \\
\text { yield, } \\
\text { Mg.ha-1 }^{-1}\end{array}$ & $\begin{array}{c}\text { Applied } \\
\text { water, } \mathrm{m}^{3} \text {.ha } \\
1\end{array}$ & $\begin{array}{c}\text { Water use } \\
\text { efficiency, Mg } \\
\mathrm{m}^{-3}\end{array}$ \\
\hline \multicolumn{7}{|c|}{ F- value } \\
\hline $\begin{array}{c}\text { Planting } \\
\text { method (M) }\end{array}$ & 2.76 & $51.98 * *$ & $26.80 * *$ & $37.72 * *$ & $76.98 * *$ & $\begin{array}{l}386.96 * \\
*\end{array}$ \\
\hline $\begin{array}{c}\text { Wing angle } \\
\text { (A) }\end{array}$ & $50.13 * *$ & $3.13 \mathrm{NS}$ & $24.91 * *$ & $7.60 *$ & $111.36^{* *}$ & $767.41 * *$ \\
\hline $\begin{array}{c}\text { Wing shap } \\
(S)\end{array}$ & $30.62 * *$ & $6.87 *$ & $9.78 * *$ & $5.60 *$ & $181.41 * *$ & $1216.15^{* *}$ \\
\hline$M * A$ & $0.68 \mathrm{NS}$ & $0.11 \mathrm{NS}$ & $0.031 \mathrm{NS}$ & 0.04 NS & $0.44 \mathrm{NS}$ & $15.06 * *$ \\
\hline$M * S$ & $2.81 \mathrm{NS}$ & $0.07 \mathrm{NS}$ & 0.18 NS & $0 \mathrm{NS}$ & $0.34 \mathrm{NS}$ & $13.41 * *$ \\
\hline$S * A$ & 0.99 NS & $0.06 \mathrm{NS}$ & $0.6 \mathrm{NS}$ & $0.17 \mathrm{NS}$ & $0.81 \mathrm{NS}$ & $76.87 * *$ \\
\hline$M * A * S$ & $0.7 \mathrm{NS}$ & $0.07 \mathrm{NS}$ & $0.04 \mathrm{NS}$ & 0.03 NS & $1.37 \mathrm{NS}$ & $11.43^{* *}$ \\
\hline
\end{tabular}

$* \mathrm{p}<0.05 \quad * * \mathrm{p}<0.01, \quad$ NS is not significant

\section{Root yield}

planting methods showed a highly significant effect $(P<0.01)$ on the root yield (Table 1). Sugar beet planted in beds with $30 \mathrm{~cm}$ rows spacing produced maximum mean root yield $\left(75.57 \mathrm{Mg} \mathrm{ha}^{-1}\right)$ followed by beds with $35 \mathrm{~cm}$ rows spacing $\left(71.45 \mathrm{Mg} \mathrm{ha}{ }^{-1}\right)$. On the other hand, the results of LSD test indicated that the differences between planting sugar beet in ridges, $50 \mathrm{~cm}$ apart, and planting on beds with $40 \mathrm{~cm}$ rows spacing was not significant (Table 2). Previous studies focused on three agronomic factors affecting the sugar beet yield (i.e., row spacing, hill spacing and plant population). In the current study, the hill spacing was maintained constant and the rows spacing was varied, this produced different plant population. Accordingly, plants population in beds was more than those in ridges. The same findings were obtained by Zahoor et al (2010). Considering the effect of wing shape on the root yield, the statistical analysis showed that the root yield was significantly affected by wing shape $(P<0.05)$. It is evident from Table 2 that the curved wing was associated with the high value of root yield (72.175 Mg ha-1) compared to the straight wing (70.745 Mg ha-1). This was attributed to increase the number of plant per unit area as a result of increasing the emergence percentage. The wing angle had no significant effect on the root yield (Table 2). 
Table 2. Mean values of sugar beet parameters as affected by planting methods, wing shape and angle.

\begin{tabular}{|c|c|c|c|c|c|c|}
\hline Planting methods & $\begin{array}{c}\text { Seed } \\
\text { Emergenc } \\
\text { e, \% }\end{array}$ & $\begin{array}{c}\text { Root } \\
\text { yield, Mg } \\
\text { ha }^{-1}\end{array}$ & $\begin{array}{c}\text { Sugar } \\
\text { Percentag, } \\
\% \\
\end{array}$ & $\begin{array}{c}\text { Sugar } \\
\text { yield, Mg } \\
\mathrm{ha}^{-1}\end{array}$ & $\begin{array}{c}\text { Applied } \\
\text { water, m3 } \\
\text { ha }^{-1}\end{array}$ & $\begin{array}{c}\text { Water use } \\
\text { efficiency, } \\
\mathrm{Mg} \mathrm{m}^{-3}\end{array}$ \\
\hline $\begin{array}{l}\text { Beds with } 40 \mathrm{~cm} \\
\text { rows spacing }\end{array}$ & 88.8 a & $68.98 \mathrm{a}$ & $18.92 \mathrm{a}$ & $12.98 \mathrm{a}$ & 7267.9 a & $9.75 \mathrm{a}$ \\
\hline $\begin{array}{l}\text { Beds with } 35 \mathrm{~cm} \\
\text { rows spacing }\end{array}$ & $88.42 \mathrm{a}$ & $71.45 \mathrm{~b}$ & $18.83 a$ & $13.40 \mathrm{a}$ & $7455.3 \mathrm{a}$ & $9.80 \mathrm{a}$ \\
\hline $\begin{array}{l}\text { Beds with } 30 \mathrm{~cm} \\
\text { rows spacing }\end{array}$ & 88.76 a & $75.57 \mathrm{c}$ & $18.79 \mathrm{a}$ & $14.13 \mathrm{~b}$ & $7663.6 \mathrm{a}$ & $10.16 \mathrm{~b}$ \\
\hline ridges $50 \mathrm{~cm}$ a part & $88.1 \mathrm{a}$ & $69.29 \mathrm{a}$ & $17.02 \mathrm{~b}$ & $11.74 \mathrm{c}$ & $9716.4 \mathrm{~b}$ & $7.26 \mathrm{c}$ \\
\hline LCD 0.05 & 1.296 & 1.458 & 0.613 & 0.565 & 452.46 & 0.234 \\
\hline \multicolumn{7}{|l|}{ Wing Angle, degree } \\
\hline 35 & $87.81 \mathrm{a}$ & 70.75 a & $17.950 \mathrm{a}$ & $12.62 \mathrm{a}$ & $8710.5 \mathrm{a}$ & $8.303 \mathrm{a}$ \\
\hline 45 & $89.22 \mathrm{~b}$ & $71.90 \mathrm{a}$ & $18.83 \mathrm{~b}$ & $13.5 b$ & $7341.1 \mathrm{~b}$ & $10.18 b$ \\
\hline LCD 0.05 & 0.418 & 1.421 & 0.359 & 0.679 & 249.54 & 0.143 \\
\hline \multicolumn{7}{|l|}{ Wing Shape } \\
\hline Straight & 87.967 a & $70.475 \mathrm{a}$ & $18.115 \mathrm{a}$ & $12.68 \mathrm{a}$ & 8899.7 a & $8.303 a$ \\
\hline Curved & $89.067 \mathrm{~b}$ & $72.175 \mathrm{~b}$ & $18.667 \mathrm{a}$ & $13.44 b$ & $7151.9 b$ & $10.18 \mathrm{~b}$ \\
\hline LCD 0.05 & 1.071 & 0.7006 & 0.598 & 0.3868 & 470.93 & 0.1623 \\
\hline
\end{tabular}

\section{Sugar percentage and yield}

Sugar percentage was highly significantly $(P<0.01)$ affected by planting methods (Table 1). The planting of sugar beet on ridges, $50 \mathrm{~cm}$ apart, was associated with low percentage of sugar compared to the other planting methods. This may attributed to the increase of the moisture content of the soil in the root area as affected by the presence of water on both sides of the ridge. On the other hand, for sugar beets planted on beds with different rows spacing there is no significant difference in sugar percentage between the different rows spacing on beds. The planting methods had a highly significant effect on sugar yield (Table 1). Sugar beet planted on beds with $30 \mathrm{~cm}$ rows spacing produced highest sugar yield (14.13 Mg ha${ }^{1}$ ), while, the lowest sugar yield (11.74 $\mathrm{Mg} \mathrm{ha}^{-1}$ ) was associated with beets planted in ridges. There is no significant effect of beets planted on beds with 35 and $40 \mathrm{~cm}$ rows spacing on sugar yield. In general, the wing shape and angle had a significant effect $(P<0.05)$ on the sugar yield (Table 1$)$. The use of the curved wing and wing angle of $45^{\circ}$ significantly increased the sugar percentage and yield compared to the straight wing and wing angle of $35^{\circ}$. 


\section{applied water}

The results of applied water to the sugar beet as affected by the planting methods, wing shape and wing angle were presented in Table 2. The statistical analysis indicated that the applied water was highly significantly affected by the planting methods, wing shape and angles. Planting beet on ridges resulted in a higher amount of irrigation water applied compared to planting beet on beds. This may attributed to the fact that the number of furrow in case of ridges was more than that in case of beds which requires more water to fill. The same findings were reported by Chaudhry et al (1994). LSD test shows that there were no significant differences between the amounts of water applied to the beds with different row spaces (Table 2). Using the curved wing and wing angle of $45^{\circ}$ led to decrease the amount of water applied compared to the straight wing and $35^{\circ}$ wing angle because the furrows profiles produced by the curve wing and $45^{\circ}$ wing angle were wider than that produced by the straight wing and $35^{\circ}$ wing angle.

\section{Water use efficiency (WUE)}

Water use efficiency was high significantly affected by the planting methods, wing angle and shape. Planting the beet on beds with $30 \mathrm{~cm}$ distance between rows induced higher water use efficiency than the other planting methods. On the other hands, the planting of sugar beet on ridges was associated with low values of water use efficiency compared to planting on beds. Data presented in Table 2 shows that the water use efficiency for the beet planted on beds was not significantly affected by changing the space between rows from $35 \mathrm{~cm}$ to $40 \mathrm{~cm}$. The maximum values of water use efficiency were associated with the curved wing and the wing angle of $45^{\circ}$ compared to straight wing and wing angle of $30^{\circ}$. This may attributed to increasing the root yield and decreasing the amount of applied water.

\section{CONCLUSION}

Based on the results obtained from this study, specific conclusions could be summarized as follows:

- The curved wing angle of $45^{\circ}$ wing angle and rake angle of $30^{\circ}$ resulted in a wide furrow profile than the other parameters tested in this study.

- The minimum transverse scattering ( $\mathrm{std}, 1.6 \mathrm{~cm}$ ) was associated with the share rake angle of $20^{\circ}$, wing angle of $35^{\circ}$ and curved wing shape.

- Increasing the share rake from 20 to $30^{\circ}$ and wing angles from 35 to $45^{\circ}$ resulted in an increase in mean values of net draft force requirement by 42 and $8.2 \%$, respectively. 
- The planting methods showed highly significant effects on the sugar percentage, sugar and root yields, amount of applied water, and water use efficiency.

- The highest values of the emergence percentage (89.22\%), root and sugar yield (71.90 and13.5 Mg ha ${ }^{-1}$, respectively), sugar percentage (18.83\%), and water use efficiency $\left(10.18 \mathrm{Mg} \mathrm{m}^{-3}\right)$ were achieved with the wing angle of $45^{\circ}$ compared to the wing angle of $35^{\circ}$.

- Curved wing caused an increase in the emergence percentage, sugar percentage, sugar and root yields, and water use efficiency, while decreased the amount of irrigation water applied.

\section{REFERENCES}

1. Abd El-Tawwab, I. M., M. E. Badaway and S. El-Khawaga. 2007. Developing and performance evaluation of a locally fabricated sugar beet planter. Misr $\mathrm{J}$. Ag. Eng., 24(4): 648-665.

2. Abo-Shady, K. A, M. Samia, E. E. Hilal, M. and M. F. Ibrahim. 2010. Yield and quality of sugar beet crop as affected by irrigation interval, cultivars and potassium fertilization in north delta. J. Agric. Res. Kafer El-Sheikh Univ., 36(4): 361-376.

3. Chaudhry, M. R., M. A Gill., M. S Arshed and M. Arif. 1994. Surface water application techniques for cotton crop to alleviate water logging and salinity. Sarhad J. Agric., 19: 461-467.

4. FAO, 1974. The euphrates pilot irrigation project. Methods of soil analysis, Gadeb Soil Laboratory (A laboratory manual). Food and Agriculture Organization, Rome, Italy.

5. Fielke, J. M. 1988. The influence on tillage of share wing geometry in a sandy loam soil. Conference on Agricultural Engineering 1988: An Australasian Conference to Celebrate the Australian Bicentennial, Preprints of Papers. Barton, ACT: Institution of Engineers, Australia, 1988: 73-77.

6. Hu, X., T. Shiheng and W. Lixiang. 1997. Research on ridge and furrow planting of proso in semi arid and Drought inclined Areas,Agricultural Reseach in the Arid Areas. 01

7. Jensen, M. E. 1983. Design and operation of farm irrigation systems. American Society of Agricultural and Biological Engineers, St. Joseph, Michigan, U.S.A., DOI: 10.13031/2013.23684

8. Mathur, S. M. and K. P. Pandey. 1992. Infulence of system parameters on performance of reversible hoe type furrow opener for animal drawn seed and 
fertilizer drills. Proceeding of the international Agricultural Engineering Conference, November 17-23, 1991, Asian Institute of Technology, Bangkok, Thailand,pp: 143-150.

9. McGinnus, R. A., 1982. Sugar beet technology. $3^{\text {ed }}$ ed. Sugar beet development foundation, Fot. Collinos.,Co, USA. 119-153

10. Ren, X., J. Zhikuanb, C. Xiaolic, H. Juand and H. Qingfang. 2013. Effect of ridge and furrow planting of rainfall harvesting on soil available nutrient distribution and root growth of summer corn under simulated rainfall conditions.Trans Chinese Soc Agric. Eng., (23): 94-99.

11. Römkens, M. J. M., S. Singarayar, C. J. Gantzer, 1986. An automated noncontact surface profileMeter. Soil Tillage Res. 6, 193-202.

12. Scott, R. K. and K. W Jaggard. 1978. How the crop grows, from seed to sugar. British Sugar Beet Rev., 46(4): 19-22.

13. Varshney, A. C. and K. V. Patel. 1988. Effect of cutting angle of shovel on unit draft andrake. Indian J. of Agricultural sciences, 58(12): 932-934.

14. Varshney, A. C., R. K. Naik, S. M. Nandy, G. S. Prajapati, and S. N. Ararang. 2006. Determination of penetration of soil working tools in clay soil. Indian Journal of Agricultural Sciences, 76 (1): 66-67.

15. Zahoor, A., P. Shah, K. M. Kakar, H. El-Sharkawi, P B. S. Gama, E. A. Khan, T. Honna and S. Yamamoto. 2010. Sugar beet (Beta vulgaris L.) response to different planting methods and row geometries II: Effect on plant growth and quality. J. of Food, Agriculture \& Environment, 8 (2): 785 - 791.

16. Zhang, C. and K. Araya. 2001. A three stage soil layer mixing plough for the improvement of meadow soil, Part II. Soil bin experiments. J. of Agricultural Engineering Research, 78(4): 359-67.

17. Wagner, L.E. and Y. Yiming. 1991. Digitization of profile meter photographs. Trans. ASAE, 34 (2), 412-416 
تأثير العوامل التصميمية لسلاح وحدة التخطيط وطرق الزراعة على إنتاجية وكفاعة

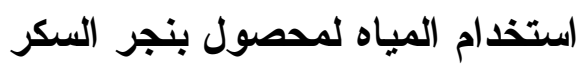

\section{سامي عبد الجيا مرعي}

معهز بحوث الهنسة الزراعية، مركز البحوث الزراعية، ص ب ror، دقي، جيزة، مصر

تهدف هذه الدر اسة الى دراسة تأثثر العو امل التصميمية لسلاح وحدة التخطيط لألة زر اعة التهاء

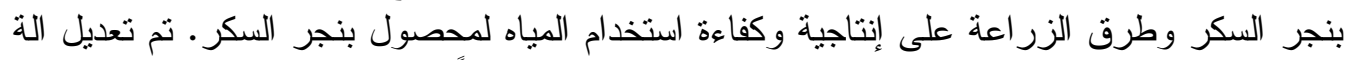

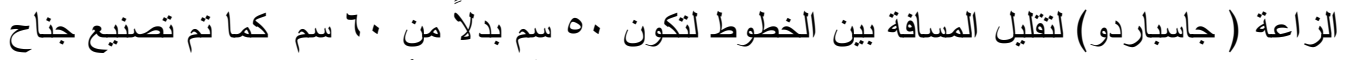

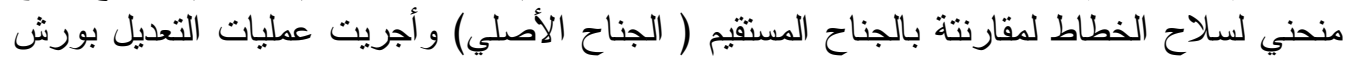
مصنع بنجر السكر بالحامول - شركة الدلتا للسكر . أجريت التجارب الحقلية بإحدى المز ارعارع الخاصة

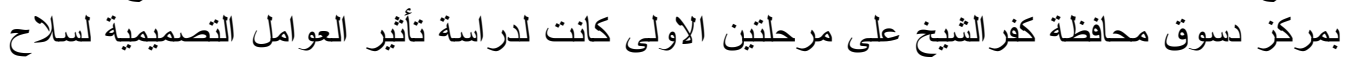

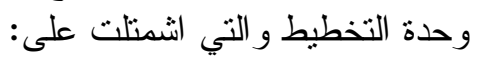

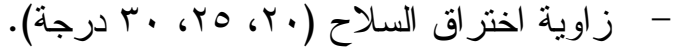

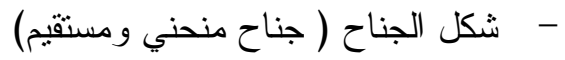

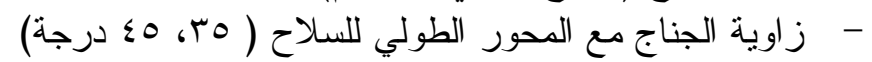

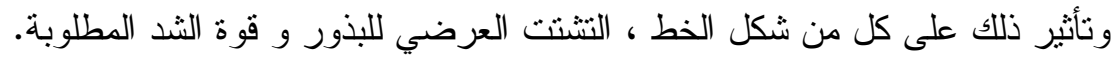

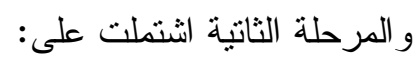

- - طرق الزر اعة ( الزر اعة على خطوط المسافة بينها ــ سم، خطين على مصاطب المسافة

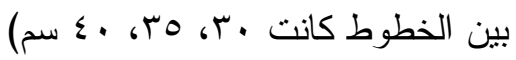

$$
\begin{aligned}
& \text { - شكل الجناح ( جناح منحني ومستقيم) }
\end{aligned}
$$

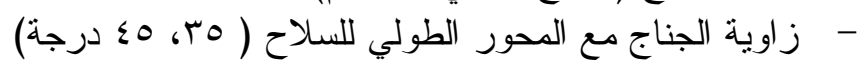

وتأثثر ذلك على نسبة الإنبات، نسبة السكر ، انتاجية الجذور و السكر ، كمية المباه المضافة، كفاءة

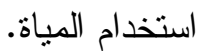

\section{وكاتت الهم النتائج التي تم الحصول عليها كما يلي:}

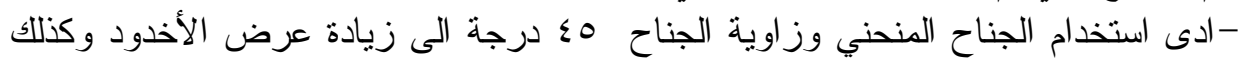

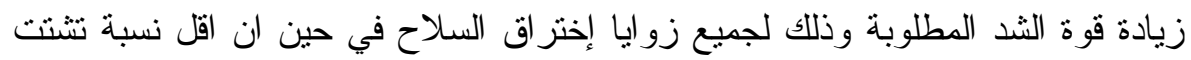

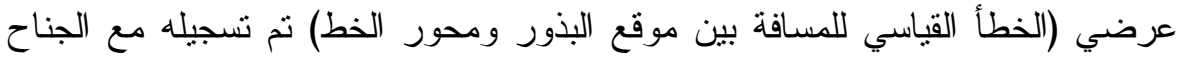

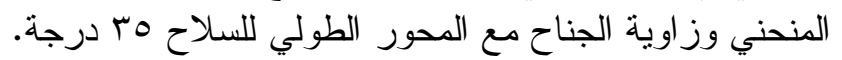
- زيادة زاوية اختر اق السلاح ادت الى زيادة عمق الاخدود وقوة الثد المطلوبة وكذللك نسبة

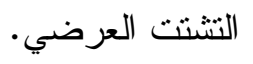

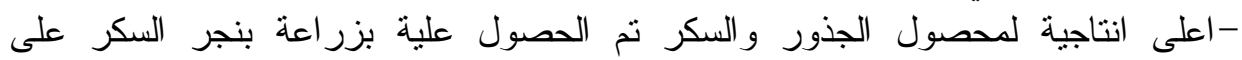

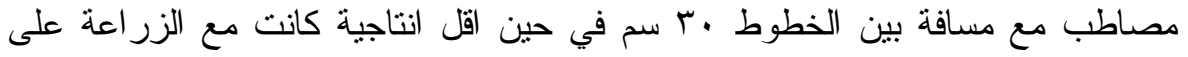
خطوط.

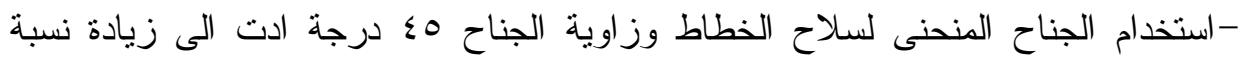

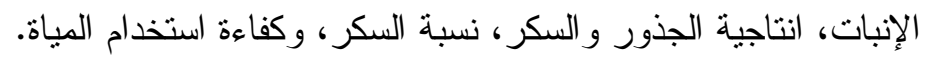

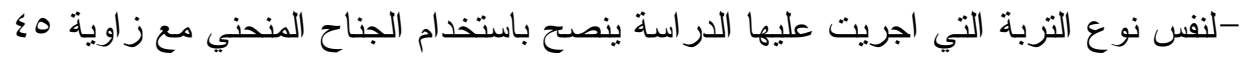

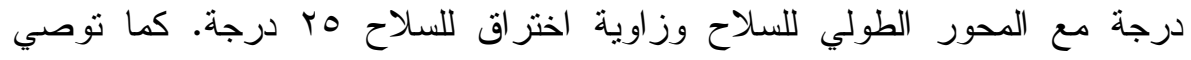
الدر اسة بزر اعة بنجر السكر على مصاطب المسافة بين الخطوط لـ سم. سم. 